\title{
Training, Working Motivation and Performance of Non-Permanent Workers-Auxiliary Staff of Agricultural Extension Workers (THL-TBPP)
}

\author{
Rinofi, Asmawi, and Zul Irfan \\ Universitas Andalas \\ e-mail: udo_ryno@yahoo.co.id
}

\begin{abstract}
This study aimed to analyze the effect of training and working motivation on performance of the non-permanent workers-auxiliary staff of agricultural extension workers (THL-TBPP) in West Sumatra. The research method used was a survey approach with quantitative methods and the techniques of data analysis used were descriptive and inductive analysis. The research results indicate that the extension management training of THL-TBPP on training material, facilitators, and training organizing aspects have been conducted very well. The extension workers' motivation of THL-TBPP regarding the needs of achievement and affiliation was very high, whilst the motivation over the authority was medium-worth. The performance of THL-BPP extension workers from the counselling preparation, implementation, counselling to the evaluation and reporting was very high in which the extension workers of THL-BPP carried out all the duty very well. The training had a significant level of $0.000<0.05$ so that it fulfilled the condition to be the supporting variable of extension workers performance. It means that if the performance of THL-TBPP extension workers in West Sumatera increases, then it is caused by one of the training done. The agricultural extension management training has given a positive impact on the improvement of THL-TBPP extension workers performance in West Sumatera. The motivation had a significance level of $0.004<0.05$ so that it has fulfilled the condition to be the supporting variable of extension workers performance as well. The high motivation for extension workers will increase the performance of THL-TBPP extension workers in West Sumatera.
\end{abstract}

Keywords: Training, Motivation and Performance of THL-TBPP

\section{Abstrak}

Penelitian ini bertujuan untuk menganalisis pengaruh pelatihan dan motivasi kerja terhadap kinerja pekerja non-permanen-staf tambahan penyuluh pertanian (THL-TBPP) di Sumatera Barat. Metode penelitian yang digunakan adalah pendekatan survei dengan metode kuantitatif dan teknik analisis data yang digunakan adalah analisis deskriptif dan induktif. Hasil penelitian menunjukkan bahwa pelatihan manajemen penyuluhan THL-TBPP. Motivasi pekerja penyuluhan dari THL-TBPP mengenai kebutuhan pencapaian dan afiliasi sangat tinggi. Kinerja petugas penyuluh THL-BPP dari persiapan konseling, implementasi, konseling hingga evaluasi dan pelaporan sangat tinggi di mana penyuluh THL-BPP melaksanakan semua tugas dengan sangat baik. Pelatihan memiliki tingkat signifikan 0,000 <0,05 sehingga memenuhi syarat untuk menjadi variabel pendukung kinerja penyuluh. Artinya jika kinerja penyuluh THL-TBPP di Sumatera Barat meningkat. Pelatihan manajemen penyuluhan pertanian telah memberikan dampak positif pada peningkatan kinerja pekerja penyuluhan THL-TBPP di Sumatera Barat. Motivasi memiliki tingkat signifikansi 0,004 <0,05 sehingga telah memenuhi syarat untuk menjadi variabel pendukung kinerja penyuluh juga. Motivasi yang tinggi untuk penyuluh akan meningkatkan kinerja penyuluh THL-TBPP di Sumatera Barat.

Kata Kunci : Komunikasi, Kebijakan, Layanan Administrasi Akademik, Badan Layanan Umum 


\section{INTRODUCTION}

To build the qualified and reliable human resource, then it is necessary to have professional, creative, innovative and global awareness extension workers in organizing the productive, effective, and efficient counselling. The extension workers are guided to carry out the mentoring and consultation task for the stakeholders and entrepreneurs in expanding their agribusiness ventures, so the adoption of appropriate technology can work well and, in its turn, it can improve the empowerment of stakeholder, production, productivity, income, and prosperity of the farmers and their family.

The Extension or counselling activities are not only carried out by civil servants. Due to a shortage of extension workers, in 2007 the government through the Ministry of Agriculture appointed nonpermanent workers-auxiliary staff of agricultural extension workers (THL-TBPP) to assist the extension activities. THL-TBPP recruited from the years 2007-2009, and to date, in 2017 they have been working for 7-10 years. Data Agricultural Training Center West Sumatra stated that THL-TBPP is only provided with the provisioning training for the extension workers, but it has not been provided with functional training of skilled and expert counselling as obtained by the civil servants in accordance with their duties.

The related phenomena of non-permanent workers-auxiliary staff of agricultural extension workers (THL-TBPP) work motivation in West Sumatra is based on observations in the area, then it is still met that 1) there are still employees who lack a strong willingness to work, 2) working time is underutilized, 3) the unconducive employment relationship, 4) work if only there is an order from the leader or boss, 5) unstable psychological condition. Therefore, it is necessary to assess the effect of training and motivation toward the performance of THL-TBPP in West Sumatra. The research purpose is to analyze the effect of training and working motivation on the performance of the non-permanent workers-auxiliary staff of agricultural extension workers (THL-TBPP) in West Sumatera.

\section{METHOD}

Research locations were selected purposively (intentionally) which is in West Sumatra, by the reason that all respondents involved in this research are the extension workers of THL-TBPP which have working area spread out in every regency or city in West Sumatra. The research was designed by using a survey approach with quantitative methods. The quantitative method is a method to test certain theories by examining the relationship between variables. The variables were measured by using the research instrument so that the data which consists of numbers or statistics can be analyzed based on statistical procedure (Creswell, 2010).

The variables observed in this research consisted of independent and dependent variables. The independent variable in this research consisted of training (X1) and working motivation (X2), whereas the dependent variable in this research is the performance of extension workers (Y1). In the research, the population is the overall participants of the counselling management training for THL-TBPP from 2016 to 2017 as many as 120 participants in West Sumatra. The sampling technique from population elements in this research was by using probability sampling with Proportional Random Sampling in which the sampling of population community was conducted randomly and it was carried out by taking a percentage of population total. In this research, the instrument was such as the compiled questionnaire structurally. So, it can be found out the information of research variables. 


\section{FINDING AND DISCUSSION}

\section{A. Descriptive Analysis}

1) Individual Characteristic Description of THL-TBPP Extension Workers in West Sumatra

The individual characteristic is a characteristic which inherents in each individual that has already existed from birth, and it is also influenced by the environment in which they grow and develop. The individual characteristics described in this research is the THL-TBPP extension workers characteristics of West Sumatra who become respondent. Things that differentiate and set up the individual characteristics of THL-TBPP extension workers are age, formal education level, and gender.

Table 4.1 shows that mostly THL-TBPP extension workers spread in the work area in West Sumatra have adult age range (30-49 years), as many as 73.9 percent. This indicates that the THL-TBPP extension workers are classified into a productive age because, according to BPS age category, the productive age range of an individual is 15-64 years.

Table 4.1. Numbers and percentages of individual age of THL-TBPP extension workers in West Sumatra

\begin{tabular}{lrr}
\hline \multirow{2}{*}{ Individual characteristics } & \multicolumn{2}{c}{ THL-TBPP } \\
\cline { 2 - 3 } & Numbers (people) & Frequency (percent) \\
\hline Age & 1 & 1.1 \\
Young (17-29 years) & 68 & 73.9 \\
Adults (30-49 years) & 23 & 25.0 \\
Elderly ( $\geq 50$ years) & 92 & 100.0 \\
\hline Total & & \\
\hline
\end{tabular}

Source: primary data

Someone's productive ability will decrease along with the age-added because someone will be increasingly difficult to accept information and adopt the technology (Riana, 2015; and Mardikanto, 2010). Therefore, Sadono (2012) states that the productive age is very important to be noted while considering that counselling activities require good quality human resources so that the activities can be implemented optimally.

Parallel with the research finding, it also shows relatively similar. Productive and adult age possessed do not only make the extension workers of THL-TBPP in West Sumatra more open and easy to accept the information, but the approach done by the extension workers to the farmers is better because of the experience, information and new technical obtained in the field through the training and learning process. It is as delivered by Muliady (2009) that someone's age is closely related to the performance, as well as the extension workers of THL-TBPP in West Sumatra. 
Table 4.2. Numbers and percentages of the individual formal education level of THL -TBPP extension workers in West Sumatra

\begin{tabular}{lcr}
\hline \multirow{2}{*}{ Individual characteristics } & \multicolumn{2}{c}{ THL-TBPP } \\
\cline { 2 - 3 } & Number (people) & Frequency (percent) \\
\hline Formal education level & 0 & 0 \\
Low (primary and secondary) & 54 & 58.7 \\
Average (High School) & 38 & 41.3 \\
High (Higher Education) & 92 & 100.0 \\
\hline Total & &
\end{tabular}

Source: primary data

The level of education of a person becomes one of the factors that affect a person's ability to receive information which then affects their performance. Various findings in the field such as Sadono (2012), Helmy et al. (2013) and Lopez (2016) showed that the level of formal education affects someone in their performance. The results of field observations also showed a similar case, in which the extension workers of THL-TBPP were quite active in seeking information to support their smooth performance. Because, unlike the civil servants who often obtain formal training activities, the training received by extension workers of THL-TBPP is not too much so that they demanded to be more active in seeking additional information. Even though, THL-TBPP extension workers are like the civil servant extension workers who have a responsibility to the fostered village and farmers.

Table 4.3. Numbers and percentages of the individual formal education level of THL -TBPP extension workers in West Sumatra

\begin{tabular}{lcr}
\hline \multirow{2}{*}{ Individual characteristics } & \multicolumn{2}{c}{ THL-TBPP } \\
\cline { 3 - 3 } & & Number (people) \\
\hline Gender & & Frequency (percent) \\
Male & 47 & 51.1 \\
Woman & 45 & 48.9 \\
\hline Total & 92 & 100.0 \\
\hline
\end{tabular}

\section{B. Data Analysis Results}

\section{1) Prerequisites Test Analysis}

Prerequisite test analysis is useful to determine how much influence of the counselling management training for THL-TBPP extension workers (X1) and motivation (X2) toward the extension workers' performance (Y). Prerequisite test analysis conducted was a hypothesis test of the regression coefficient partially and thoroughly toward the regression equation. The following explanation shows the data findings generated through a trial which used SPSS 25.00 program.

\section{a) Normality test}

Normality Test is a test conducted to assess the data distribution in a data group or variable, whether the data is normally distributed or not. Normality test aims to test whether the dependent and independent variables in the regression model has a normal distribution or not. A good regression model is to have the normal data distribution or close to normal which the point (data) is accumulated around the line. The normality test is conducted by using P-P graphic of a plot which can be found in Appendix 3 . 
The graphic of normality test results showed in Appendix 3 is obtained through the analysis of SPSS 25.00 program. Based on the normality test, the similarity between the expected-probability and the observation probability percentage can be seen. the similarity of the expected-probability percentage and the observation probability percentage are shown by the diagonal line of the expected-probability which does not differ greatly with the observation probability. From the graphic, it can be seen that the percentage of plot P-P is located around up to touch the diagonal line and not deviate far. This means that the distribution of data on each variable, namely the data of training and motivation effect toward the performance of THL-TBPP extension workers, is normally distributed.

\section{b) Multicollinearity Test}

Multicollinearity test is used to find out whether there is any multicollinearity classical assumption deviation or not, it means that there is a linear relationship between the independent variables in the regression model. Prerequisites that must be completed in the regression model is the absence of multicollinearity. Ghozali (2005) stated that the guideline of a multicollinearity-free regression model is to have a VIF (Variance Influence Factor) percentage less than 10 and to have tolerance percentage close to 1 . Table 4.5 shows the result of multicollinearity test such a percentage of Variance Influence Factor (VIF) and tolerance based on the research data by using SPSS 25.00.

Table 4.5. Results of Test Multicollinearity

\begin{tabular}{lrr}
\hline \multirow{2}{*}{ Model } & \multicolumn{2}{c}{ Collinearity Statistics } \\
\cline { 2 - 3 } (Constant) & Tolerance & VIF \\
Training &, 931 & 1.074 \\
Motivation &, 931 & 1.074 \\
\hline
\end{tabular}

Sources: Primary data is processed with SPSS 25.00

Based on the analysis result in Table 4.5, VIF percentage on two independent variables in the research were under 10 and a tolerance percentage close to 1 . This means that there is no multicollinearity between the independent variables, namely training (X1) and motivation (X2). Therefore, it can be concluded that the independent variable complied with the requirements of the classical assumptions about multicollinearity.

\section{c) Heteroscedasticity Test}

Heteroscedasticity test is a test to assess whether there are inequality variants of residuals for all observations in a linear regression model. Sketchily, this test is done to predict whether the regression model used is suitable or not. If the heteroscedasticity assumptions are fulfilled, then the regression model is declared valid as a forecasting instrument. On the other hand, if the heteroscedasticity assumption is not fulfilled, then the regression model is declared invalid as a forecasting tool.

The method often used To detect heteroscedasticity in SPSS software is by looking up to whether there are certain patterns in scatterplots or not that show the relation between Regression Studentized Residuals and Regression Standardized Predicted Value. The basis of making decisions related to the picture are:

1) If there are certain patterns, i.e. if the points form a certain pattern and it is regular (fluctuated, widened then narrowed), then there is a heteroscedasticity problem indicated.

2) If there is no clear pattern, i.e. if the points spread, then there is no heteroscedasticity problem indicated. 
Heteroscedasticity test results of the research data by using SPSS 25.00 could be seen in the graph shown in Appendix 4. According to Appendix 4, it shows that the points on the graphic spread so there is no clear pattern. This indicates that there is no heteroscedasticity problem in the regression model in this research data.

\section{d) Linearity Test}

Generally, the linearity test aims to determine whether the two variables have a linear relationship or not significantly. A good correlation there should be a linear relationship between the independent variable $(\mathrm{X})$ with the dependent variable (Y). Test in SPSS by using the Test for Linearity with the significance level of 0.05 . Two variables are considered to have a linear relationship when significance (Linearity) is less than 0.05 . Table 4.6 shows the linearity test results of research data processed by using SPSS 25.00.

Table 4.6. Linearity Test Results

\begin{tabular}{lcc}
\hline \multicolumn{1}{c}{ Model } & F & Sig. \\
\hline (Constant) & & \\
Training & 2.948 &, 000 \\
Motivation & 11.239 &, 000 \\
\hline
\end{tabular}

Sources: Primary data is processed with SPSS 25.00

Table 4.6 shows that, from the results of data processing using SPSS 25.00, the significant percentage of the training and motivation variables are obtained. The variable significance results of training and motivation showed a smaller percentage of 0.05 , so it can be concluded that there is a significant linear relationship in training and motivational variables toward the performance of THLTBPP extension workers.

\section{2) Multiple Linear Regression Analysis Test}

Multiple linear regression test in this research aimed to see whether there is influence between the two independent variables (free) which consists of training (X1) and motivation (X2) regarding the dependent variable, that is the performance (Y). Multiple linear regression tests were carried out by using SPSS 25.00. Table 4.7 shows the results of multiple linear regression analysis.

Table 4.7. The results of multiple linear regression analysis

\begin{tabular}{lrrr}
\hline \multicolumn{1}{c}{ Variables } & $\begin{array}{c}\text { The regression } \\
\text { coefficient }\end{array}$ & $\mathrm{t}_{\text {counting }}$ & sig. \\
\hline Constant & 18.457 & 3.985 &, 000 \\
Training (X1) &, 194 & 4,415 &, 000 \\
Motivation (X2) &, 512 & 2.973 &, 004 \\
\hline $\mathrm{F}$ & 18.925 & &, $000 \mathrm{~b}$ \\
\hline $\mathrm{t}$ table & & 1.98698 &, 283 \\
\hline R square & & &
\end{tabular}

Sources: Primary data is processed with SPSS 25.0 (2019) 
Based on Table 4.7, multiple linear regression equation obtained as follows :

$\mathrm{Y}=18.457+0,194 \mathrm{X} 1+0.512 \mathrm{X} 2$

Where :

$\mathrm{Y}=$ Performance

a $=$ Constant

$\mathrm{b}=$ Partial Regression Coefficients

$\mathrm{X} 1=$ Training

$\mathrm{X} 2$ = Motivation

Based on the equation above, it can be concluded as follows:

a) The constant percentage of 18.457 in the model of multiple linear regression equation above can means that without the influence of training and motivation, the percentage of performance has been reached 18.457 .

b) The regression coefficient of motivation variable (X2) is at 0.512 , This means if the percentage of motivation is increased by one unit, the percentage on the performance of THL-TBPP extension workers will increase by 0512 in each unit. This means that if the motivation percentage is greater, then the performance percentage of THL-TBPP in conducting counselling activities will also be greater or will increase. Thus, when it is compared with other variable coefficients, the motivation percentage is at first in influencing the performance of THL-TBPP.

c) The regression coefficient of training variable (X1) is at 0.194 , This means if the training percentage increase by one unit, then the percentage on performance THL-TBPP extension workers will increase by 0194 in each unit. This means that if the training percentage is greater, then the performance percentage of THL-TBPP in conducting counselling activities will also increase. Thus, when it is compared with other variable coefficients, the percentage of the training is at second in influencing the performance of THL-TBPP.

\section{3) Discussion of Training Effects on Performance THL-TBPP in West Sumatra}

The results of multiple linear analysis show that there is a significant effect on the real level of 0.05 in the management training of agricultural extension toward the performance of THL-TBPP extension workers in West Sumatra, with the regression coefficient percentage of 0.194. This means that each increase of one unit of training received by extension workers, it will give effect to increase the performance of THL-TBPP extension workers around 19.4 percent. Likewise, if there is a decrease of one unit of training received by extension workers, there will be a performance decreasing of extension workers around 19.4.

It shows that the training provides a significant effect on the performance of THL-TBPP extension workers in West Sumatra in carrying out the counselling. Based on the observations in the area, it is known that the training followed by THL-TBPP extension worker is not as many as training followed by civil servants. This is one of the causes of the insufficient influence given by training on improving the performance of extension workers in carrying out counselling. Nevertheless, it remains influential because, with the training, extension workers acquire new knowledge, as well as a change in attitude and skills in which later it will be applied in carrying out the counselling activities in the field. This is in line with Mc. Kenna (2000) that the training received can improve the workers' changing skill.

Education and knowledge do not only gain knowledge, but it also can improve the working skill of THL-TBPP extension, thereby it can improve the effectiveness of extension services, as also mentioned by Simanjuntak (1985). Education and training are the processes of building up the THL-TBPP extension workers to become a professional one so that they can produce better output. 
Through the agricultural extension management training followed by THL-TBPP extension workers in West Sumatra, each of the extension worker is expected to gain new abilities and skills, or even to develop the ability and skill that have already had to become better. Therefore, the Department of Agriculture, Horticulture and Plantation of West Sumatra as the official government institution which has responsible to THL-TBP has an obligation in the provision of training required by THL-TBPP extension workers, so it can improve the extension workers' knowledge and skill so that their performance can increase.

\section{4) Discussion of Motivation Effect on The Performance THL-TBPP in West Sumatra}

The results of multiple linear analysis shown in Table 4.7 shows that there is a significant influence in the real level of 0.05 in the extension workers' motivation toward the performance of THL-TBPP in conducting the agricultural extension in West Sumatra, with the regression coefficient percentage is 0.512. It means that each increase of one unit of motivation in the extension, it will give an effect toward the performance increase of THL-TBPP extension workers around 51.2 percent. Likewise, if there is a decrease in one unit of the workers' motivation, there will be a worker's performance decreasing around 51.2 percent. This suggests that motivation is a variable that provides the most powerful influence in comparison with other variables in influencing the performance of THL-TBPP extension workers in carrying out the agricultural extension activities.

The findings indicate that the workers' motivation especially the motivation to an affiliate or cooperate with other parties, either with fellow extension workers, officials in a government institution, as well as the farmers, becomes the strongest motivation for the workers in improving the performance. This is as the findings of Pramod et al. (2017) and Hernanda (2015) which states that the level of extension workers needs in affiliation is in the highest category because the extension workers have a great desire to participate in helping farmers to improve their prosperity and to build a joint network in terms of capital and marketing. The need for affiliation becomes a motivator which motivates the spirit at work so it increases more the working desire for extension workers because everyone wants things such as the need for feeling accepted by others in the neighbourhood they lived and worked (sense of belonging), the need for feelings of respect, because every human feels they are important (sense of importance), the need for a feeling of progress and not being failed (sense of achievement), and the need for a feeling of participation (sense of participation). A person, due to the affiliation need, will motivate and develop themselves and use all their energy to complete tasks (Robbins, 1996).

The high motivation of extension workers, either in terms of the desire to excel, the desire to affiliate, or the desire to be powerful, can increase the competency and performance of THL-TBPP extension workers in West Sumatra in carrying out agricultural extension activities. It is like the findings of Nuryanto (2008) and Ma'ruf et al., (2010) who found that the influence of motivation on a very significant competency increasing. If the extension workers' motivation for THL-TBPP in West Sumatra is improved, the workers' performance will also increase. The high support motivation is shown by the high need for achievement and a very high need for affiliation. This is in line with the findings of Lesmana (2016) who states that motivation in the form of achievement needs, affiliation needs, and power needs simultaneously influence the performance of extension workers. 


\section{CONCLUSION}

Training (X1) significantly affects the performance (Y) of THL-TBPP extension workers in West Sumatra. The training has a significance level around $0.000<0.05$, so that it adequates to be variable of extension workers' performance support. This means that if the performance of THL-TBPP extension workers in West Sumatra increases, then this is caused, one of them, by training conducted. The agricultural extension management training provides a positive impact on the increasing of THL-TBPP extension performance in West Sumatra.

Motivation (X2) significantly affect the performance (Y) of THL-TBPP extension workers in West Sumatra. The motivation has a significant level of $0.004<0.05$, so it adequates to be variable of extension workers' performance support. The high motivation for extension workers will improve the performance of THL-TBPP workers in West Sumatra.

\section{SUGGESTION}

The training held for THL-TBPP extension workers should be more improved either in quality and quantity. The training managed can be a non-technical training and capacity building of THL-TBPP extension workers according to the needs and problems in the field. The extension institutions in West Sumatra particularly need to keep motivating extension workers, such as personally inviting the extension workers to dialogue and create a relaxing atmosphere or by visiting extension workers in the work field. Great motivation and good support from extension services will be able to help more the improvement of THL-TBPP extension workers' performance in conducting the extension maximally

\section{BIBLIOGRAPHY}

[1]. Anoraga, Panji, (1995). Psikologi Kerja. Jakarta : Rineka Cipta.

[2]. Arikunto, Suharsimi. (2002). Prosedur Penelitian, Suatu Pendekatan Praktek. Jakarta: Rineka Cipta.

[3]. Asnawi, S (2002). Teori Motivasi. Jakarta: Studia Press.

[4]. Barry, Cushway. (2002). Human Reource Management. Jakarta: PT. Elex Media Kumputindo.

[5]. Bahua, M. I. (2018). Peran Motivasi dan Kinerja Penyuluh Pertanian dalam Mengubah Perilaku Petani Jagung. Jurnal Sosial Ekonomi Pertanian. 14(3): 225-232.

[6]. Dessler, Gary. (2009). Manajemen Sumber Daya Manusia. Jakarta: PT. Prenhalindo.

[7]. Dharma, Agus. (2001). Manajemen Prestasi Kerja. Yogyakarta: Rajawali.

[8]. Flippo, Edwin B. (2010). Manajemen Personalia. Jakarta: PT. Gelora Aksara Pratama.

[9]. Gallerman, Soul W. (1984). (Terjemahan Soepomo S. Wardoyo). Motivasi dan Produktivitas. Jakarta: Pustaka Binaman Pressindo. 
[10]. Gomes, Faustino Cardoso. (2000). Manajemen Sumber Daya Manusia, Cetakan Keempat. Yogyakarta. Penerbit Andi.

[11]. Handoko, T. Hani (2007). Motivasi Daya Penggerak Tingkah Laku. Jakarta: Konsensus.

[12]. Saputra, T. (2016). Pengaruh Motivasi Kerja Terhadap Disiplin Kerja Pegawai Pada Dinas Pemuda Dan Olahraga Provinsi Riau. Jurnal Niara, 8(2), 50-60. 